\title{
Effect of Methotrexate on the Liver Enzymes and Lipid Profile in Adult Female Albino Mice
}

\author{
Sabah N. Alwachi * Yasmin L. Alsaadi* \\ Received 25,December,2011 \\ Accepted 14,May,2012
}

\begin{abstract}
:
Methotrexate (MTX) was used for treatment of malignancies and now is widely used in treatment of rheumatoid arthritis. In this research the evaluation of the effects of MTX on some liver enzymes and lipid profile was studied. Twenty four adult female mice divided into three groups ( 8 mice each). The first two groups were treated with MTX while the third group was used as a control. MTX was intraperitoneally given at $50 \mu \mathrm{g} / \mathrm{ml}$ and $75 \mu \mathrm{g} / \mathrm{ml}$ to the first and second groups respectively for 35 days, whereas the control group was intraperitoneally injected with normal saline. The results showed a significant $(\mathrm{p}<0.05)$ increase in serum levels of glutamic oxaloacetate transaminase (GOT), glutamic pyruric transaminase (GPT), Alkaline phosphatase (ALP), total cholesterol and triglyceride (TG), however high density lipoprotein (HDL) showed a significant $(\mathrm{p}<0.05)$ decrease in mice treated by MTX when compared with control group .
\end{abstract}

Key words : (MTX) Methotrexate, (GOT) glutamic oxaloacetate Transaminase, (GPT)Glutamic Pyruric Transaminase, (ALP) alkaline phosphatase, (TG) triglyceride, (HDL) high density lipoprotein, (LDL-c) low density lipoprotein-cholesterol .

\section{Introduction:}

Methotrexate (MTX) is commonly used as a cytotoxic agent in the treatment of leukemia and other malignancies as well as in the inflammation diseases such as psoriasis and rheumatoid arthritis in lower doses [1]. With the widespread use of MTX, although hepatotoxicity is the most important potential major side effect [2]. Methotrexate used for cancer chemotherapy are well known to produce a cute toxic side effects in multiple organ systems. The most common target organs are bone marrow, gastrointestinal tract, mucosal membrane, and hair follicles [3]. It has been reported that liver damage may occur as well in particular high doses or following chronic administration of MTX [4]. However,long-term

administration of MTX is associated with an increase risk of liver damage. The risk for development of liver disease is not often predicted with the use of standard liver enzymes and thus, patients receiving MTX must be monitored routinely by examination of liver biopsies [5].

The mechanisms of action of MTX are complex, and proposed to inhibits purine and pyrimidine synthesis, which accounts for its efficacy in the therapy of cancer as well as for some of its toxicities. Certain aspects of MTX toxicities are also attributed to adenosine release [6]. As MTX promotes adenosine release acting at its receptor and mediates the immunologic and anti-inflammatory effects of MTX in the treatment of

* Department of Biology, College of Science, Universityof Baghdad 
rheumatoid arthritis [7]. One long-term adverse effect of MTX is hepatotoxicity [8]. In rheumatoid arthritis patients receiving doses of MTX, a biopsy should be performed if a patient develops persistent abnormalities on liver blood tests. The suggestion is that biopsies be performed after every 1 to $2 \mathrm{~g}$ of cumulative MTX therapy [9]; [10] , because liver function tests were not an effective form of monitoring for methotrexate hepatotoxicity [11]. The aim of this research is to study the effects of chemotherapy drug (methotrexate) on liver enzymes and lipid profile levels in mice .

\section{Materials and Methods:}

Twenty four adult female albino mice with 8-10 weeks of age , and 2530 grams of weight were used in this study . All mice were provided with food and water ad libitum. The mice were divided into three groups, (each composed of eight mice). The first and second groups received intraperitoneal injections of MTX at $50 \mu \mathrm{g} / \mathrm{ml}$ and 75 $\mu \mathrm{g} / \mathrm{ml}$ respectively, whereas control group was given normal saline for 35 days. The room temperature was maintained at $(24 \pm 2){ }^{\circ} \mathrm{C}$, and the animals were exposed to 14 hours light 10 hours darkness program.

Methotrexate was obtained from (Hexal company) at concentration of (50mg $/ 2 \mathrm{ml}$ ), the stock solution of MTX was $(25 \mathrm{mg} / \mathrm{ml})$, and from it the concentration $50 \mu \mathrm{g} / \mathrm{ml}, 75 \mu \mathrm{g} / \mathrm{ml}$ were prepared to be used in this study .

\section{Biochemical examination}

\section{1- Lipid profile}

Determination of total cholesterol, triglyceride and HDL in the serum were measured by enzymatic kit method produced by biomerux (France) according to [12].

Determination of liver enzymes
Glutamic

Oxaloacetate

Transaminase (GOT) \&Glutamic Pyruric Transaminase (GPT)

The GOT and GPT enzymes activity were evaluated in mice serum by using enzymatic colorimetric kit method (Randox company) and according to [13] .The absorbency was measured at $546 \mathrm{~nm}$ by using spectrophotometer .

ALP (alkaline phosphates)

To estimate the activity of the ALP enzymes, procedure of [14] was used.

\section{Statistical Evaluation}

Data were analyzed by SPSS version 10 with analysis of variance with ANOVA- test. Data are presented as means \pm SD and the level of significancy was equal to less than $0.05[15]$.

\section{Results and Discussion:}

In the present study the result showed a significant $(\mathrm{p}<0.05)$ increase in serum levels of liver enzymes (GOT.GPT, ALP), in mice treated by MTX comparing with control group (Table 1).This finding suggestes that MTX can inflame the liver and causing abnormal serum levels of liver enzymes . 
Table (1): Serum levels of liver enzymes in mice treated with MTX and control

\begin{tabular}{|l|l|l|l|}
\hline Groups & $\begin{array}{l}\text { GOT IU/ml } \\
(\text { mean } \pm \text { SD) }\end{array}$ & $\begin{array}{l}\text { GPT IU/ml } \\
(\text { mean } \pm \text { SD) }\end{array}$ & $\begin{array}{l}\text { ALP IU/ml } \\
(\text { mean } \pm \text { SD) }\end{array}$ \\
\hline & $\mathrm{A}$ & $\mathrm{A}$ & $\mathrm{A}$ \\
Control & $214.63 \pm 16.19$ & $62.07 \pm 9.41$ & $74.22 \pm 11.83$ \\
\hline MTX & $\mathrm{B}$ & $\mathrm{B}$ & $\mathrm{B}$ \\
$(50 \mu \mathrm{g} / \mathrm{Kg})$ & $287.05 \pm 23.37$ & $88.05 \pm 14.47$ & $134.27 \pm 21.07$ \\
\hline MTX & $\mathrm{B}$ & $\mathrm{B}$ & $\mathrm{B}$ \\
$(75 \mu \mathrm{g} / \mathrm{Kg})$ & $291.05 \pm 32.92$ & $92.91 \pm 13.06$ & $141.84 \pm 34.20$ \\
\hline
\end{tabular}

\section{Differences $A, B$ are significant $(P<0.05)$ in compared rows}

It was reported that the increase of GOT ,GPT serum levels may be due to the cytotoxic effect of MTX on liver cells. This may lead to increase the permiability of liver cell membrane, causing the movement of high quantity of these enzyme to blood serum .This explains the increases of the enzyme level in blood serum and decreases in liver after using these toxic agents [16] . Kremer et al.[10] demonstrated that hepatotoxic effects are associated with long-term use and high doses of MTX and are common in patients taking a daily dose.However in patients with rheumatoid arthritis, the treatment with MTX; lead to persistent elevation in liver enzymes. Methotrexate is also known to be widely used as a therapeutic agent in different diseases, and connected with various side effects, including liver toxicity. The mouse model used in this study clearly demonstrate the toxic effects of this drug as there is an increase in the death rate, as well as the significant increase of GOT and GPT levels. It was reported that MTX administered in conjugation with either nicotinamide or methionine, the rise in the death rate and in GOT and GPT levels is markedly reduced [17]. Griffith et al. [18] reported that MTX is effective in rheumatoid arthritis but it can induce abnormalities in liver function test. The study is also showed that folate supplementation can reduce the incidence of elevated liver enzymes during MTX treatment. Hepatic damage is also reported to be in relation to MTX use and combined with the elevation of liver enzymes,GOT and GPT released into the blood [19] . Morever Robert et al. [20] found that ALP and transaminase were significantly increased in patients at the time of starting (or restarting) MTX therapy. The elevation of ALP level is correlated with the severity of the toxic effect of MTX. Palazzi et al. [21] found that the administration of MTX at $10 \mathrm{mg}$ caused an increase in transaminase. Also the administration of folinic acid with $7.5 \mathrm{mg}$ of MTX was reported to increase transaminase enzyme. However the reduction in MTX dose with folate administration were unable to normalize serum transaminase. While the use of ursodeoxycholic acid progressively reduced liver enzymes to normal levels. Belinsky et al. [22] using mice, reported that long-term administration of MTX for management of chronic inflammatory disease is associated with risk of liver damage, MTX-induced liver inflammation may be mediated by elevation of complement pathway gene expression . Complement is produced by hepatocytes secreted in high amounts into the blood. Activation of the complement pathway results in a cascade of liver enzymatic events producing amplification of response. The results of the present study are also showed a significant $(\mathrm{p}<0.05)$ 
increase in serum levels of total cholesterol and triglyceride, while high density lipoprotein (HDL) level was significantly $(\mathrm{p}<0.05)$ decreased in mice treated with MTX in comparison to control group (Table 2) .Our data indicate that MTX is associatedwith increase levels of total cholesterol, TG and decrease level of HDL, all

Table (2): Levels of lipid profile in mice treated with MTX and control

\begin{tabular}{|c|c|c|c|}
\hline Groups & $\begin{array}{l}\text { T.Chol. } \\
\text { mg/dl } \\
(\text { mean+SD) }\end{array}$ & $\begin{array}{l}\text { T.G } \mathrm{mg} / \mathrm{dl} \\
(\text { mean+SD) }\end{array}$ & $\begin{array}{l}\mathrm{HDL} \mathrm{mg} / \mathrm{dl} \\
(\mathrm{mean} \pm \mathrm{SD})\end{array}$ \\
\hline Control & $\begin{array}{l}\mathrm{A} \\
122.30 \pm 21.07\end{array}$ & $\begin{array}{l}\text { A } \\
97.04 \pm 18.63\end{array}$ & $\begin{array}{l}\mathrm{A} \\
29.50 \pm 4.28\end{array}$ \\
\hline $\begin{array}{l}\text { MTX } \\
(50 \mu \mathrm{g} / \mathrm{Kg})\end{array}$ & $\begin{array}{l}\text { B } \\
243.85 \pm 26.92\end{array}$ & $\begin{array}{l}\mathrm{B} \\
189.55 \pm 21.92\end{array}$ & $\begin{array}{l}\mathrm{B} \\
16.22 \pm 4.01\end{array}$ \\
\hline $\begin{array}{l}\text { MTX } \\
(75 \mu \mathrm{g} / \mathrm{Kg})\end{array}$ & $\begin{array}{l}\text { C } \\
266.71 \pm 37.82\end{array}$ & $\begin{array}{l}\mathrm{C} \\
204.62 \pm 41.04\end{array}$ & $\begin{array}{l}\mathrm{B} \\
15.29 \pm 5.03\end{array}$ \\
\hline
\end{tabular}

\section{Differences $A, B, C$ are significant $(P<0.05)$ in compared rows}

Similarly Georgiadis et al. [23] demonstrated that post MTX treatment the levels of cholesterol, triglyceride and low density lipoprotein-cholesterol (LDL-c) were significantly elevated when compared to the control values ,the inflammation reported after the treatments in all of these experiments is responsible for the elevation of these lipid profile parameters. Belinsky et al. [22] reported that 35 genes involved in fatty acid synthesis were upregulated in the MTX-exposed samples and this was in consistent with frequent steatosis associated with MTX exposure. Fatty metamorphosis is a hallmark of MTX-induced hepatotoxicity. Also van Ede et al. [24] found that the use of MTX can cause a folic acid deficiency with subsequently higher homocysteine levels and, thereby, increasing the risk of cardiovascular disease by increasing levels of total cholesterol, LDL-c, TG and reduction in serum HDL-c level of these parameters are important aspects and cause increasing the development of atherosclerosis and subsequently clinically overt cardiovascular disease . which is in consistence to the finding repoted in the present study.

\section{References:}

1- Sener, G.; Demiralp, E.E.; Cetiner, M.; Ercan, F.; Sirvanci, S.; Gedik, N. and Yegen, B.C. 2006 L-carnitine ameliorates methotrexate-induced oxidative organ injury and inhibits leucocyte death. Cell Biol. Toxicol. 22:47-60.

2- West, S.G. 1997 Methotrexate hepatoxicity. Rheum. Dis. Clin. North Am. 23: 883-915.

3- Kim, J.C.; Kim, K.H. and Chung, M.K. 1999 Testicular cytotoxicity of DA-125, a new anthracycline anticancer agent, in rats. Reprod. Toxicol. 13: 391-397.

4- Uraz, S.; Tahan, V.; Aygun, C.; Eren, F.; Unluguzel, G.; Yuksel, M.; Senturk, O.; Avsar, E.; Haklar, G.; Celikel, C.; Hulagu,S. and Tozun, N. 2008 Role of ursodeoxycholic acid in prevention of methotrexate-induced 
liver toxicity. Dig. Dis. Sci. 53: 10711077.

5-Richard, S.; Guerret, S.; Gerard, F.; Tebib, J.G. and Vignon, E. 2000 Hepatic fibrosis in rheumatoid arthritis patients treated with methotrexate: Application of a new semi-quantitative scoring system. Rheumatology (Oxford) 39: 50-54.

6-Tian, H. and Cronstein, B.N. 2007 Understanding the mechanisms of action of methotrexate: implications of the treatment of rheumatoid arthritis. Bull.NYU.Hosp.Jt. Dis. 65(3):168173.

7-Chan, E.S. and Cronstein, B.N. 2010 Methotrexate- how does it really work?. Nat.Rev.Rheumatol. 6:175-178.

8-Tolman, K.G.; Clegg, D.O.; Lee, R.G. and Ward, J.R. 1985 Methotrexate and the liver. J. Rheumatol. 12:29-34.

9-Roenigk, H.H. J.; Auerbach, R.; Mailbach, H.I. and Weinstein, G.D. 1982 Methotrexate guidelinesrevised. J. Am. Acad. Dermatol. 6:145155.

10-Kremer, J.M.; Alarcon,G.S.; Lightfoot,R.W.;Willkens,R.F.;

Furst,D.E.; Williams,H.J.; Dent,P.B. and Weinblatt, M.E. 1994 Methotrexate for rheumatoid arthritis: suggested guidelines for monitoring liver toxicity. Arthritis Rheum. 37:316328.

11-Cueller, M.L. and Espinoza, L.R. 1997 Methotrexate use in psoriasis and psoriatic arthritis. Rheum. Dis. Clin. North Am. 23:797-809.

12- Sale, F.O.; Morchesini, S.; Fishmann, P.H. and Berra, B. 1984 A sensitive enzymatic assay for determination of cholesterol in lipid extract. Anat.Biochem. 142: 347-350 .

13- Reittman, S. and Frankel, S1957 Clinical biochemistry. Amer. J. Clin. Path. 28: 56

14- Bomers, G.N. and McComb, R.B. 1975 Guidelines on standard operating procedures for clinical chemistry .Clin.Chem. 21: 1988-1995.
15- Cronstein, B.N.; Naime, D. and Ostad, E. 1993 The antiinflammatory mechanism of methotrexate. J.Clin. Invest. 92: 2675-2682.

16- Bonnefoi, M.; Hasim ,M.;Sauvagnac ,P.; Burgat, V.; and Braun, J.P. 1989 Liver enzyme changes in a Guinea-pig model of facial eczema (sporidesmiotoxicosis ) . Enzyme . 42:39-46.

17- Kröger, H.; Hauschild, A.; Ohde, M.; Bache, K.; Voigt, W.P.; Thefeldt, W. and Krüger, D. 1994 Nicotinamide and methionine reduce the liver toxic effect of methotrexate . Gen. Pharmacol.: The Vascular System, 33(2): 203-206 .

18- Griffith, S.M.; Fisher, J.; Clarke, S.; Montgomery, B.; Jones, P.W.; Saklatvala, J.; Dawes, P.T.; Shadforth, M.F.; Hothersall, T.E.; Hassell, A.B. and Hay, E.M 2000 Do patients with rheumatoid arthritis established on methotrexate and folic acid $5 \mathrm{mg}$ daily need to continue folic acid supplements long term? Rheumatology, 39:11021109.

19- Diouf, M.L.; Diallo, S.; Mbengue, M. and Moreira-Diop, T. 2001 Methotrexate, liver and rheumatoid arthritis in tropical areas. Arthritis Rheum. 11(3): 195-200.

20- Robert, P.; Baughman, M.D.; Allison-Koehler, M.D.; Pablo,A.; Bejarano, M.D.; Elyse, E.; Lower,M.D.; Fredrick, L. and Weber, J.M.D. 2003 Role of liver function tests in detecting methotrexate-induced liver damage in sarcoidosis. Arch.Intern.Med. 163: 615-620.

21- Palazzi, C.; D’Amico, E.; Pennese, E.; and Petricca, A. 2003 Normalization of methotrexate-induced high levels of serum transaminases after ursodeoxycholic acid administration in a rheumatoid arthritis patient. Rheumatology .42(10): 12661267. 
22- Belinsky, G.S.; Parke, A. L.; Huang, Q.; Blanchard, K.; Jayadev, S.; Stoll, R.; Rothe, M.; Achenie, L. E. K.; Gupta, R.R.; Wu, G.Y. and Rosenberg, D.W. 2007 The Contribution of Methotrexate Exposure and Host Factors on Transcriptional Variance in Human Liver. Toxicol. Sci. 97 (2): 582-594.

23- Georgiadis, A.N; Papavasiliou, E.C.; Lourida, E.S.; Alamanos, Y.; Kostara, C.; Tselepis, A.D. and Drosos, A.A. 2006 Atherogenic lipid profile is a feature characteristic of patients with early rheumatoid arthritis: effect of early treatment - a prospective, controlled study. Arthritis Res. Ther. 8(3): 82-88.

24- van Ede, A.E.; Laan, R.F.; Blom, H.J.; Boers, G.H.; Haagsma, C.J.; Thomas, C.M.; De Boo, T.M. and van de Putte, L.B. 2002 Homocysteine and folate status in methotrexate-treated patients with rheumatoid arthritis. Rheumatology(Oxford). 41(6): 658665.

\section{تأثير عقار الميثوتركسيت على انزيمات الكبد وصورة الدهون في اناث الفئران البيض البالغة البية}

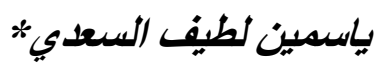

*باح ناصر العلوجي

$$
\text { *قسم علوم الحياة، كلية العلوم، جامعة بغداد }
$$

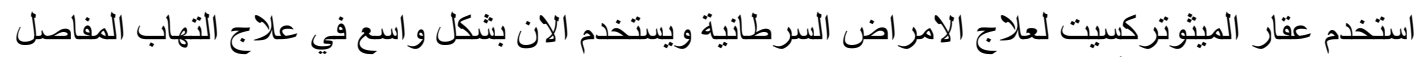

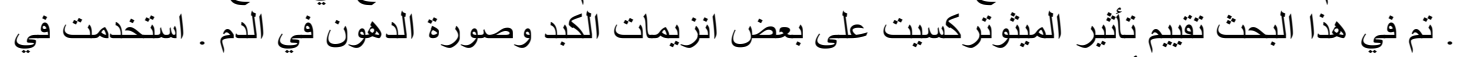

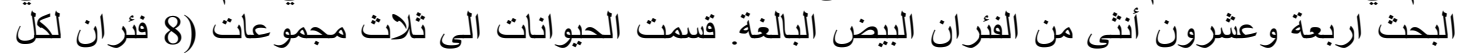

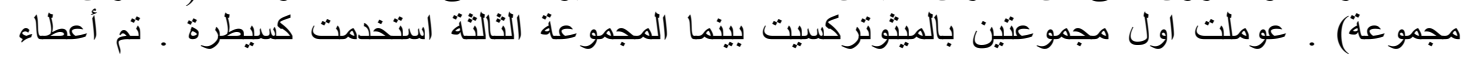

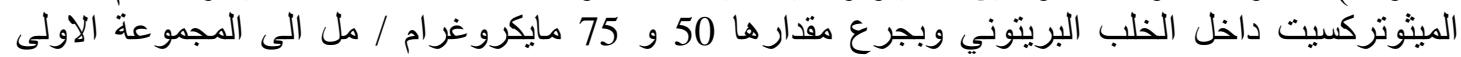

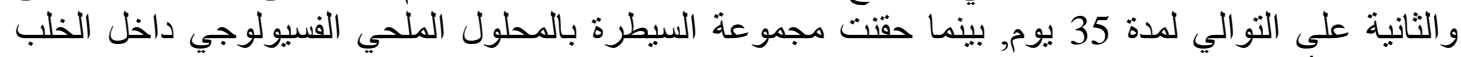

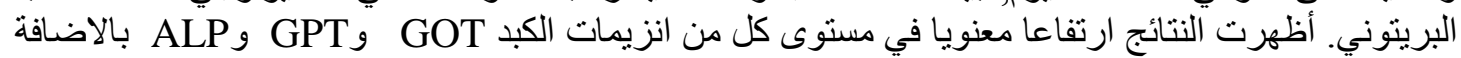

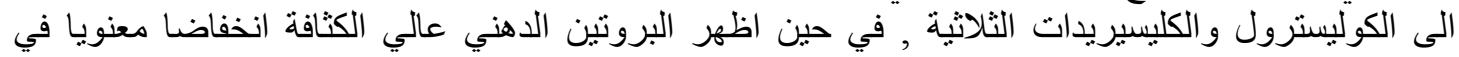

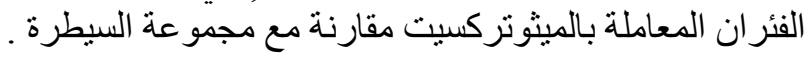

